\title{
Mobilitet: konstnärer, konstverk och ett begrepp i förändring
}

Marie-Sofie Lundström

Hösten 2017 ordnades det tionde nationella konsthistorikersymposiet TAHITI. Temat var Mobilities: Artist, Art Works and a Concept in Change och symposiet ordnades av Föreningen för konsthistoria i samarbete med konstvetenskap vid Åbo Akademi. Konferensens övergripande syfte var att diskutera begrepp som "mobilitet" och "resande" i olika former inom ramen för konstvetenskap och visuell kultur, i dialog med forskning inom andra discipliner. Huvudtalaren Dr. Nina Lübbren från Anglia Ruskin University i Cambridge, Storbritannien talade om "Place myths and mobilities: From Barbizon to Bollywood", därtill fick åhörarna ta del av tio föredrag som alla berörde mobilitet på ett eller annat sätt: utopisk ruinmelankoli; konstnärskolonin i Önningeby på Åland; Juho Rissanens hälsoresa i Biskra; konsthistoriska expeditioner i Finland under 1800-talet; Helsingfors Kunsthalles vandringsutställningar under kalla kriget; Loja Saarinens roll som textilkonstens pionjär i USA; Petri Ala-Maunus landskapsmåleri; symbolisk mobilitet och identitet i kinesisk samtidskonst; motorvägar; och internationella konstnärsresidens i slutet på 1900-talet.

Föredragshållarna erbjöds möjligheten att delta i ett temanummer i denna nättidskrift; i detta nummer får vi läsa fyra bidrag i form av vetenskapliga artiklar som bygger på den egna presentationen. Dessa artiklars och presentationers diversitet berättar tydligt att mobilitet förekommer i de mest skiftande former. Förutom resor i det inre och i det verkliga berättar de tydligt att mobilitet som begrepp har mångfaldiga innebörder. I vardagslag står ordet för rörelseförmåga eller tillgång till fri rörlighet, men i konstvetenskapliga sammanhang tillkommer andra innebörder som behöver definieras och förtydligas. Konsthistoriker uppmärksammar mobilitet när de studerar hur konstnärer reser för att studera och utvecklas, men här kan termen också syfta på utbyte av idéer, eller interaktionen mellan sådana aktörer i konstlivet som samlare, konstgallerier och konstsamlande institutioner. Konstnärer är i likhet med konstälskare rörliga, och även konstverken transporteras 
för såväl temporär utställning som permanent placering på nya platser och hos nya ägare. Utöver konstvärldens växlande och föränderliga topografi kan frågeställningar om mobilitet också gälla idéers rörlighet. Platsens myter är ett annat problemområde som gäller "alternativa geografier", platser i marginalen, försvunna platser, utsuddade topografier, resor till det förgångna, och nostalgi. Slutligen, som det inkluderande begrepp det är, kan mobiliteten också vara en metafor för inre resor bakåt eller framåt $\mathrm{i}$ tiden, i en individuell fantasi eller inom ramen för en kollektiv utopi.

Jag önskar er alla trevlig läsning.

Pargas, 8.3.2019 